\title{
Study of the geochemical processes of radionuclides of oil and gas fields
}

\author{
Tatyana Glushkova, Aleksei Kachkin, Ivan Nejmyshev, Aleksandr Talalaj * , and Irina \\ Shinkaryuk
}

Ural State Mining University, 620144 Ekaterinburg, Russia

\begin{abstract}
The objects of study of the geochemical processes of radionuclides are deposits of the West Siberian Plate, the distribution of radioactive elements in the areas of the Tyumen oil and gas region. In the process of work, the chemical composition of sedimentary rocks was investigated, and the mass fractions of uranium, radium, thorium, potassium, and other chemical elements were determined. Data on the distribution of radionuclides in individual wells and areas were considered, correlation diagrams of geochemical specificity were constructed. To determine the mass fractions of uranium, radium, thorium, potassium, and other chemical elements, gamma spectrometric, neutron activation, X-ray spectral, and laser-luminescent measurements were used. In order to control the measurement results, the determination of uranium in the samples was duplicated using the delayed neutron method in a specialized facility. The accuracy of uranium determination, estimated from independent measurements, was $\sim 6.4 \%$ (rel.). The radioactive equilibrium is shifted towards uranium, which indicates an increase in the mass fractions of naturally radioactive elements in the raw of sandstones sandstone-siltstone open pits - siltstones. The increase of the level of natural radioactivity in the direction from sandstones to siltstones is explained by the difference in brittleness between quartz and grains of active accessories, which indicates a stable ratio between radium and uranium in the sandstones-siltstones in relation to the considered areas of the Tyumen region.
\end{abstract}

The objects of study of the geochemical processes of radionuclides are deposits of the West Siberian Plate, the distribution of radioactive elements in the areas of the Tyumen oil and gas region.

In the process of work, the chemical composition of 144 sedimentary rocks was investigated, and the mass fractions of uranium, radium, thorium, potassium, and other chemical elements were determined. Data on the distribution of radionuclides in individual wells and areas were considered, correlation diagrams of geochemical specificity were constructed.

The shift of radioactive equilibrium towards uranium indicates an increase in the mass fractions of naturally radioactive elements in the raw of sandstones - sandstone-siltstone

\footnotetext{
${ }^{*}$ Corresponding author: groupnedra@mail.ru
} 
open pits - siltstones. The growth of the level of natural radioactivity in the direction from sandstones to siltstones is explained by the difference in brittleness (ability to disintegrate) between quartz and grains of active accessories, which indicates a stable ratio between radium and uranium in the sandstones-siltstones in relation to the considered areas of the Tyumen region.

A geochemical process is understood as physical and chemical natural reactions, as a result of which atoms and compounds are distributed in space and in time to achieve the equilibrium characteristic under given hydrothermal conditions of the earth's environment. Classification of geochemical processes can be carried out at the place of their impact, according to the features of the manifestation in combination or of individual elementary physical, chemical, biological and mechanical processes.

The processes of formation of oil and gas complexes, including accumulations of oil and gas that occurred during the large-scale migration of oil and gas components in a significant volume of carrier bed masses, are accompanied by a redistribution of radionuclides. In this case, the latter are fixed in the form of unstable compounds capable to react subsequently again to the mobile state.

The high radioactivity of coal complexes, in which most of the anomalies of ionizing radiation are concentrated, is largely a consequence of the large-scale migration of hydrocarbons and the formation of their aqueous emulsions, which dissolve radionuclides during oil and gas accumulation. The processes of oxidation and dissipation of hydrocarbon deposits can lead to the migration of mobile forms of trace elements, including radionuclides in oils and near-surface waters, to the surface in a stream of water vapor, carbon dioxide, nitrogen, and hydrocarbons during the natural process of the development of a water-oil system on a geological time scale [1].

For most samples from sediments of the West Siberian Plate, the hypothesis of a normal distribution of radioactive elements can be accepted. This conclusion is confirmed by other researchers. At the same time, correlations between radioactive elements, especially between uranium and thorium, are very characteristic for Mesozoic deposits (Table 1, Fig. 1).

Table 1. Correlations between radioactive elements in the full granulometric spectrum of sedimentary rocks of Western Siberia.

\begin{tabular}{|l|c|c|c|c|}
\hline \multicolumn{1}{|c|}{ Rock } & $\begin{array}{c}\text { Samples } \\
\text { qty }\end{array}$ & $\begin{array}{c}\text { Th }- \\
\text { K }\end{array}$ & $\begin{array}{c}\text { U }- \\
\text { T }\end{array}$ & $\begin{array}{c}\text { U - } \\
\text { K }\end{array}$ \\
\hline By Gavshin V. M. [2]: & 220 & 0.46 & 0.86 & 0.29 \\
$\begin{array}{l}\text { Cretaceous sediments } \\
\text { Jurassic sediments }\end{array}$ & 245 & 0.70 & 0.80 & 0.58 \\
\hline $\begin{array}{l}\text { Our data: } \\
\text { Jurassic and Cretaceous }\end{array}$ & 100 & 0.35 & 0.86 & 0.30 \\
sediments & & & & \\
\hline
\end{tabular}

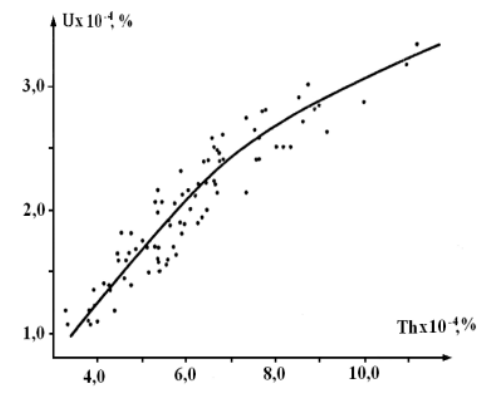

Fig.1. Relation of uranium and thorium content. 
Cretaceous and Jurassic aleuropelites contain approximately two times more uranium and thorium than in sandstones. It is appropriate to give a generalized table of the distribution of radioactive elements in the series of sandstones - siltstones - argillites, which summarizes the data obtained by different authors for deposits of Western Siberia (Table 2) $[2,3]$.

Table 2. Generalized assessments of the distribution of radioactive elements in Mesozoic terrigenous sediments.

\begin{tabular}{|c|c|c|c|c|}
\hline Rock & $\begin{array}{l}\text { Samples } \\
\text { qty }\end{array}$ & $\mathbf{T h}-\mathbf{K}$ & $\mathbf{U}-\mathbf{T}$ & $\mathbf{U}-\mathbf{K}$ \\
\hline \multicolumn{5}{|l|}{$\begin{array}{l}\text { Assessment of Gavshin } \\
\text { V. M. }\end{array}$} \\
\hline \multicolumn{5}{|l|}{ Jurassic sediments } \\
\hline Aleuropelites, argillites & 138 & 3.0 & 9.5 & 2.44 \\
\hline Siltstones & 33 & 2.3 & 6.5 & 1.70 \\
\hline Sandstones & 74 & 1.6 & 4.9 & 1.72 \\
\hline \multicolumn{5}{|l|}{ Cretaceous sediments } \\
\hline Aleuropelites, argillites & 93 & 2.5 & 9.1 & 2.18 \\
\hline Sandstones & 127 & 1.2 & 4.2 & 2.00 \\
\hline \multicolumn{5}{|l|}{$\begin{array}{l}\text { Assessments of Pluman } \\
\text { I. I. }\end{array}$} \\
\hline Argillites & 47 & 2.6 & 7.3 & 2.2 \\
\hline Siltstones & 25 & 2.1 & 7.1 & 2.2 \\
\hline Sandstones & 58 & 1.8 & 5.8 & 2.2 \\
\hline \multicolumn{5}{|l|}{ Our assessments } \\
\hline $\begin{array}{l}\text { Siltstones } \\
\text { Sandstones }\end{array}$ & $\begin{array}{l}48 \\
52\end{array}$ & $\begin{array}{l}2.3 \\
1.8\end{array}$ & $\begin{array}{l}6.8 \\
5.4\end{array}$ & $\begin{array}{l}2.05 \\
2.00\end{array}$ \\
\hline $\begin{array}{l}\text { Note - Assessments of } \\
\text { deviations of measuring the } \\
\text { Gavshin are close to ours } \\
\text { determined by GSM, ours - }\end{array}$ & $\begin{array}{l}\text { I. I. do no } \\
\text { ations of ra } \\
\text { ts of uran }\end{array}$ & $\begin{array}{l}\text { in data } \\
\text { ive elem } \\
\text { f Pluman }\end{array}$ & $\begin{array}{l}\text { specifice } \\
\text { he asses } \\
\text { nd Gavs }\end{array}$ & $\begin{array}{l}\text { Standard } \\
\text { of V.M } \\
\text { M. are }\end{array}$ \\
\hline
\end{tabular}

Table 3. Average values of mass fractions of naturally radioactive elements and their ratio in sandstones and siltstones of some areas of Western Siberia

\begin{tabular}{|c|c|c|c|c|c|c|c|c|c|c|c|c|c|c|c|}
\hline \multirow[b]{2}{*}{ 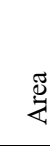 } & \multirow{2}{*}{$\begin{array}{l}\ddot{0} \\
\stackrel{0}{2}\end{array}$} & \multirow{2}{*}{ हี } & \multirow{2}{*}{$\overline{\overline{0}}$} & \multirow{2}{*}{$\begin{array}{l}\overrightarrow{0} \\
\stackrel{\overline{0}}{0}\end{array}$} & \multicolumn{3}{|c|}{$\mathrm{U}, \mathrm{g} / \mathrm{t}$} & \multicolumn{3}{|c|}{ Th, g/t } & \multicolumn{3}{|c|}{$\begin{array}{l}\mathrm{Ra} \text {, in eq. } \\
\mathrm{U}, \mathrm{g} / \mathrm{t}\end{array}$} & \multirow{2}{*}{$\sum_{\overparen{I}}$} & \multirow{2}{*}{ ఇ } \\
\hline & & & & & $\min$ & $\begin{array}{l}\mathrm{ma} \\
\mathrm{x}\end{array}$ & av. & $\min$ & $\max$ & av. & $\min$ & $\begin{array}{l}\text { ma } \\
x\end{array}$ & av. & & \\
\hline \multirow[t]{2}{*}{ 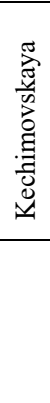 } & 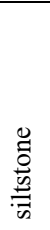 & $\vec{\sim}$ & $\ddot{n}$ & 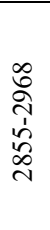 & $\begin{array}{l}1.5 \\
1\end{array}$ & 2.8 & $\begin{array}{l}2.0 \\
3\end{array}$ & $\begin{array}{l}3.7 \\
9\end{array}$ & 7.31 & $\begin{array}{l}5.8 \\
8\end{array}$ & $\begin{array}{l}0.7 \\
7\end{array}$ & $\begin{array}{l}2.0 \\
3\end{array}$ & $\begin{array}{l}1.2 \\
6\end{array}$ & $\stackrel{0}{0}$ & 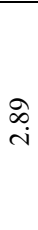 \\
\hline & 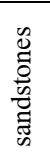 & 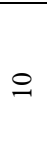 & $\underset{\forall}{\forall}$ & 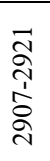 & $\begin{array}{l}1.4 \\
2\end{array}$ & $\begin{array}{l}2.1 \\
3\end{array}$ & $\begin{array}{l}1.7 \\
8\end{array}$ & $\begin{array}{l}4.1 \\
4\end{array}$ & 7.39 & $\begin{array}{l}5.6 \\
9\end{array}$ & $\begin{array}{l}0.7 \\
7\end{array}$ & $\begin{array}{l}1.7 \\
1\end{array}$ & $\begin{array}{l}1.2 \\
3\end{array}$ & $\tilde{0}$ & $\stackrel{\vartheta}{m}$ \\
\hline 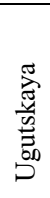 & 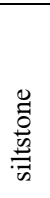 & 9 & in & 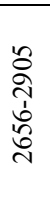 & 1.3 & $\begin{array}{l}2.3 \\
9\end{array}$ & $\begin{array}{l}1.9 \\
0\end{array}$ & 3.5 & 9.5 & $\begin{array}{l}5.5 \\
6\end{array}$ & $\begin{array}{l}0.8 \\
7\end{array}$ & $\begin{array}{l}1.4 \\
5\end{array}$ & 1.0 & กี & $\widehat{\grave{\lambda}}$ \\
\hline
\end{tabular}


Continuation of Table 3. Average values of mass fractions of naturally radioactive elements and their ratio in sandstones and siltstones of some areas of Western Siberia

\begin{tabular}{|c|c|c|c|c|c|c|c|c|c|c|c|c|c|c|c|}
\hline & 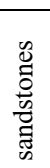 & in & $n$ & 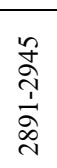 & $\begin{array}{l}1.6 \\
5\end{array}$ & $\begin{array}{l}2.6 \\
4\end{array}$ & $\begin{array}{l}1.9 \\
4\end{array}$ & $\begin{array}{l}4.4 \\
4\end{array}$ & 7.56 & $\begin{array}{l}5.4 \\
1\end{array}$ & $\begin{array}{l}0.7 \\
2\end{array}$ & $\begin{array}{l}1.7 \\
5\end{array}$ & $\begin{array}{l}1.0 \\
6\end{array}$ & $\begin{array}{l}n \\
n \\
0\end{array}$ & $\stackrel{\infty}{\stackrel{i}{i}}$ \\
\hline & & t & ి & 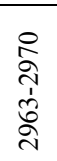 & $\begin{array}{l}2.0 \\
6\end{array}$ & $\begin{array}{l}2.7 \\
4\end{array}$ & $\begin{array}{l}2.3 \\
3\end{array}$ & 3.5 & 7.32 & 5.3 & $\begin{array}{l}1.4 \\
4\end{array}$ & $\begin{array}{l}1.6 \\
4\end{array}$ & $\begin{array}{l}1.5 \\
4\end{array}$ & $\stackrel{\bullet}{:}$ & $\widehat{\widehat{N}}$ \\
\hline \multirow[t]{2}{*}{ 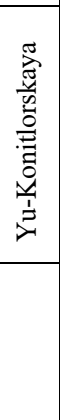 } & 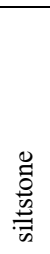 & $\Xi$ & ถิ & 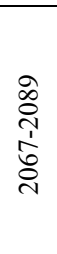 & 1.7 & 2.9 & 2.4 & $\begin{array}{l}5.3 \\
5\end{array}$ & $\begin{array}{l}10.0 \\
1\end{array}$ & $\begin{array}{l}7.3 \\
7\end{array}$ & $\begin{array}{l}1.1 \\
2\end{array}$ & $\begin{array}{l}1.8 \\
3\end{array}$ & $\begin{array}{l}1.4 \\
0\end{array}$ & $\stackrel{\infty}{n}$ & $\stackrel{i}{i}$ \\
\hline & & $\infty$ & $\widetilde{\sigma}$ & 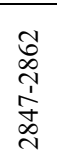 & $\begin{array}{l}1.1 \\
1\end{array}$ & $\begin{array}{l}2.8 \\
3\end{array}$ & $\begin{array}{l}2.2 \\
3\end{array}$ & $\begin{array}{l}3.9 \\
5\end{array}$ & 9.34 & $\begin{array}{l}7.6 \\
9\end{array}$ & $\begin{array}{l}0.6 \\
3\end{array}$ & $\begin{array}{l}1.7 \\
8\end{array}$ & $\begin{array}{l}1.3 \\
9\end{array}$ & $\stackrel{\tilde{\sigma}}{0}$ & $\stackrel{?}{\stackrel{n}{r}}$ \\
\hline \multirow[t]{3}{*}{ 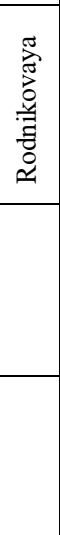 } & 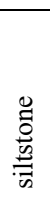 & 0 & f & $\begin{array}{l}\text { ते } \\
\text { İ } \\
\stackrel{\text { ন }}{+}\end{array}$ & $\begin{array}{l}1.9 \\
3\end{array}$ & 3.4 & $\begin{array}{l}2.6 \\
6\end{array}$ & $\begin{array}{l}6.3 \\
6\end{array}$ & 9.19 & $\begin{array}{l}7.3 \\
8\end{array}$ & $\begin{array}{l}1.2 \\
7\end{array}$ & $\begin{array}{l}2.3 \\
2\end{array}$ & 1.8 & $\begin{array}{l}\infty \\
\stackrel{\infty}{0} \\
0\end{array}$ & $\stackrel{\text { \} }{i}} \\
{\hline} &{ } &{m} &{\text { ले }} &{\text { 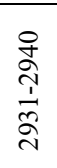 }} &{\begin{array}{l}1.4 \\
6\end{array}} &{2.2} &{\begin{array}{l}1.9 \\
3\end{array}} &{\begin{array}{l}4.6 \\
1\end{array}} &{6.27} &{\begin{array}{l}5.4 \\
1\end{array}} &{\begin{array}{l}0.9 \\
9\end{array}} &{\begin{array}{l}1.3 \\
5\end{array}} &{\begin{array}{l}1.2 \\
5\end{array}} &{\stackrel{n}{6}} &{\stackrel{\infty}{i}} \\
{\hline} &{ } &{N} &{\text { ఉా }} &{\text { 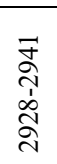 }} &{\begin{array}{l}1.5 \\
6\end{array}} &{\begin{array}{l}2.2 \\
5\end{array}} &{1.9} &{\begin{array}{l}5.5 \\
5\end{array}} &{9.29} &{\begin{array}{l}7.4 \\
2\end{array}} &{\begin{array}{l}0.6 \\
8\end{array}} &{\begin{array}{l}1.3 \\
6\end{array}} &{\begin{array}{l}1.0 \\
2\end{array}} &{\tilde{n}} &{\vec{r}} \\
{\hline \multirow[t]{3}{*}{\text { 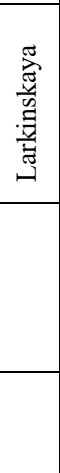 }}\text { 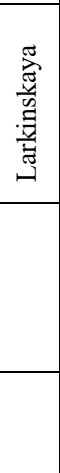 }} &{\text { 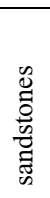 }} &{\nabla} &{\text { 卞 }} &{\begin{array}{l}\stackrel{0}{d} \\
\underset{\mathbf{D}}{0} \\
\stackrel{\sim}{\sim}\end{array}} &{\begin{array}{l}1.2 \\
4\end{array}} &{1.4} &{\begin{array}{l}1.3 \\
2\end{array}} &{3.9} &{4.2} &{4.1} &{\begin{array}{l}0.3 \\
8\end{array}} &{\begin{array}{l}0.4 \\
8\end{array}} &{\begin{array}{l}0.4 \\
3\end{array}} &{\text { กొ? }} &{\vec{m}} \\
{\hline} &{ } &{ } &{ } &{\text { 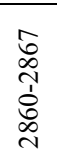 }} &{\begin{array}{l}1.3 \\
7\end{array}} &{1.7} &{\begin{array}{l}1.5 \\
5\end{array}} &{3.9} &{5.09} &{4.5} &{\begin{array}{l}0.8 \\
3\end{array}} &{\begin{array}{l}1.1 \\
2\end{array}} &{\begin{array}{l}0.9 \\
7\end{array}} &{\text { 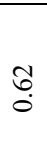 }} &{\hat{i}} \\
{\hline} &{ } &{ } &{ } &{ } &{\begin{array}{l}1.2 \\
4\end{array}} &{1.7} &{\begin{array}{l}1.4 \\
3\end{array}} &{3.9} &{5.09} &{4.3} &{\begin{array}{l}0.3 \\
8\end{array}} &{\begin{array}{l}1.1 \\
2\end{array}} &{0.7} &{\text { f̊ }} &{\stackrel{\rho}{r}} \\
$\hline
\end{tabular}

Table. 3 is also indicative for this purpose, which contains data on the distribution of radioactive elements in individual wells and areas. It can be said about the approximately 
sustained distribution of uranium and thorium over the area of the studied basin; it is controlled by the granulometric distribution, and as a consequence, the mineral composition of the rocks [4].

One of the features of the geochemistry of small, rare and rare-earth elements in sediments of Western Siberia is their gravitation to each other with predominant accumulation in the pellite fraction of rocks. The indicated regularity can be traced for the vast majority of series of the Cretaceous and Jurassic age. The closest connection is observed between $\mathrm{U}, \mathrm{Th}, \mathrm{Ti}, \mathrm{La}, \mathrm{Nd}, \mathrm{Sm}, \mathrm{Ta}, \mathrm{Hf}$ and some other elements. The question of the mineral form in the rock remains open, since the correlation coefficient $\tau \sim 0.8-0.95$ suggests that they are included together in the crystal lattice of individual minerals [5].

The nature of the $\mathrm{C}_{\mathrm{gl}}$ bond with the chemical composition of the medium, in particular, with radioactive elements is of the greatest interest. The mineral composition largely determines the type of correlation dependencies. Table 4 shows that, for deposits of different ages, the tightness of the bond between potassium, uranium, and thorium with a particle size distribution is sufficiently maintained. At the same time, the $\mathrm{C}_{\mathrm{gl}}-\mathrm{C}_{\text {mica }}$ bond is critical for the age and facies of the rocks.

For example, for $\mathrm{БC}_{\mathrm{I}-5}$ beds, it can be concluded that potassium is included in the composition of micaceous minerals, and for $\mathrm{KB}_{8}$ it can be found in micas, FS, and clay. However, $\tau \sim 0.7-0.8$ of uranium, thorium with $\mathrm{C}_{\text {mica }}$ is insufficient for such statements, which allows to speak about the gravitation of the sizes of mica particles in finely siltstone and clay fractions.

The relative fraction of these elements grows towards fine fractions, however, their partial contribution to the total gamma activity of the rock is small and cannot determine the correlation $\mathrm{C}_{\mathrm{gl}}=F(\mathrm{U}, \mathrm{Th}, \mathrm{K})$ with $\mathrm{C}_{\mathrm{gl}}$ less than $15-20 \%$. Considering carbonate cement as an obstacle in the accurate estimation of $\mathrm{C}_{\mathrm{gl}}, \tau$ were calculated for a sample excluding this factor. For them, $\tau(\mathrm{U}-\mathrm{C}<0.05)=0.68 ; \tau(\mathrm{Ra}-\mathrm{C}<0.05)=0.63 ; \tau(\mathrm{Th}-\mathrm{C}<0.05)=0.065$; $\tau(\mathrm{K}-\mathrm{C}<0.05)=0.12$, Fig. 2 and 3 .

Table 4. Correlation between radioactive elements and individual components of Neocomian sandstones (according to V.M. Gavshin, 1979).

\begin{tabular}{|c|c|c|c|c|c|c|}
\hline \multirow{2}{*}{ Components } & \multicolumn{3}{|c|}{ Bed БВ8 } & \multicolumn{3}{|c|}{ Bed БC $1-5$} \\
\hline & U & $\mathrm{T}$ & $\mathrm{K}$ & U & $\mathrm{T}$ & $\mathrm{K}$ \\
\hline$C>0.25$ & - & - & - & - & - & - \\
\hline C 0.25-0.1 & - & - & - & - & - & - \\
\hline C 0.1-0.05 & 0.52 & 0.46 & 0.36 & 0.68 & 0.66 & - \\
\hline C $0.05-0.01$ & 0.58 & 0.68 & 0.37 & 0.68 & 0.68 & - \\
\hline $\mathrm{C}<0.01$ & 0.53 & 0.62 & - & 0.62 & 0.65 & - \\
\hline Q & - & - & -0.39 & - & - & - \\
\hline FS & - & - & 0.33 & - & - & - \\
\hline $\mathrm{C}_{\text {mica }}$ & 0.50 & 0.48 & 0.49 & 0.74 & 0.86 & 0.92 \\
\hline
\end{tabular}

Thus, the tightness of the $\mathrm{C}_{\mathrm{gl}}=F(\mathrm{U}, \mathrm{Th})$ bond for most deposits of Western Siberia does not exceed $\tau=0.065-0.75$ with $\tau(\mathrm{U}-\mathrm{Th})=0.8-0.9$. Uranium and thorium are part of the same mineral formations, mainly mica and accessory minerals (sphene, leucoxene, zircon, apatite, etc.). In specific radioactivity they make up 30-50\%. The rest of uranium and thorium is associated with the contribution of FS, quartz, and clay minerals. The $\mathrm{C}_{\mathrm{gl}}=F(\mathrm{U}, \mathrm{Th})$ bond is largely determined by the contents of mica and accessories in the fraction of less than $0.05 \mathrm{~mm}$, i.e., facial and age criteria. For some deposits, a deviation 
from this general pattern may be observed due to the influence of organic matter on the distribution of uranium.

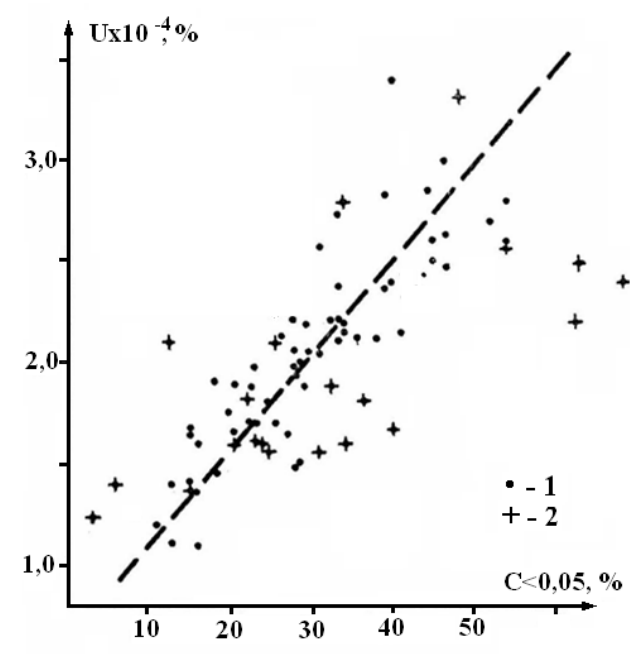

$1-\triangle \mathrm{Kpp}<15 \% ; 2-\triangle \mathrm{Kpp}>15 \%$

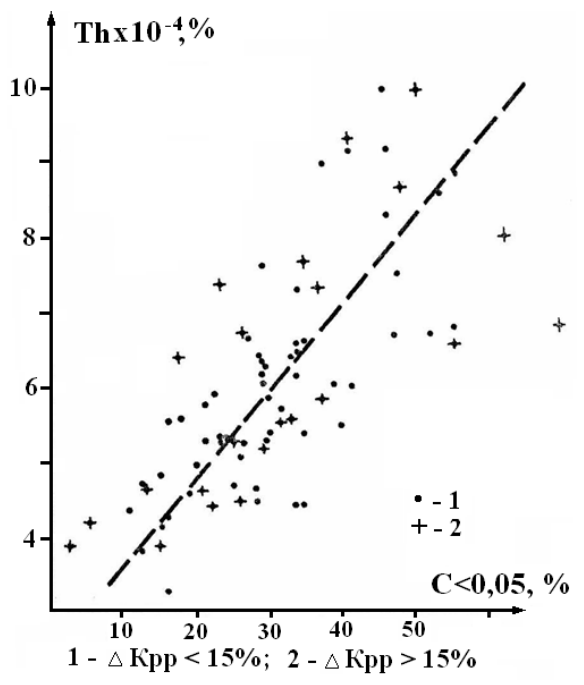

Fig.3. The relationship of the thorium content with a fraction of less than $0.05 \mathrm{~mm}$
Fig.2. The relationship of the uranium content with a fraction of less than $0.05 \mathrm{~mm}$

Potassium in most cases is a hindrance to $\mathrm{C}_{\mathrm{gl}}$ assessment from natural radioactivity logging curve.

The accuracy of the $\mathrm{C}_{\mathrm{gl}}$ determination by the regression levels of $\mathrm{C}_{\mathrm{gl}}=F(\mathrm{U}, \mathrm{Th}, \mathrm{K})$ as a whole in Western Siberia does not exceed $20-25 \%$ rel. It can be improved when building bonds for individual horizons and series (up to 5-10\% rel.). Additional information on the content of some major elements $(\mathrm{Si}, \mathrm{Al}, \mathrm{K}, \mathrm{Na}, \mathrm{Fe})$ and the thermal-neutron adsorption section will help to evaluate the main components of the mineral composition $\left(\mathrm{C}_{\mathrm{gl}}, \mathrm{C}_{\text {carb}}\right.$, $\mathrm{C}_{\text {sisand, }}, \mathrm{Cal}_{\text {sand }}$ ) with an error of up to $4 \%$. In some cases, the information on the separate content of uranium and thorium will not increase the accuracy of the $\mathrm{C}_{\mathrm{gl}}$ assessment. Therefore, it is sufficient to record the GR curve in the well with a lower discrimination threshold $\mathrm{E}_{\gamma} \sim 1.60 \mathrm{MeV}[6]$.

Using various (mainly nuclear-physical) methods of analysis of the substance, the chemical composition features of 144 sedimentary rock samples (sandstones, siltstones) taken from the core material of wells drilled at Tevlinskaya, Taylakovskaya, Ugutskaya, Yakkun-Yakhskaya, Kechimovskaya, Rodnikovaya, Yuzhno-Kontilorskaya and Larkinskaya areas of the Tyumen oil and gas region were studied.

To determine the mass fractions of $\mathrm{U}, \mathrm{Ra}, \mathrm{To}, \mathrm{K}$ and other chemical elements, gamma spectrometric ( $\mathrm{Ra}, \mathrm{Th}, \mathrm{K})$, neutron activation (Al, Na), X-ray spectral (U, Th), and laserluminescent (U) measurements were used [7-9]. In order to control the measurement results, the determination of uranium in the samples was duplicated using the delayed neutron method in a specialized facility [10]. The accuracy of uranium determination, estimated from independent measurements, was $\sim 6.4 \%$ (rel.). The average values of the contents of naturally radioactive elements in samples of sandstones and siltstones taken over different areas noticeably differ from each other. The maximum values of the mass fractions of uranium and thorium are characterized by sedimentary rocks of the $\mathrm{Yu}-$ Konitlorskaya and Rodnikovaya areas, consisting, respectively, by uranium: $2.35 \times 10^{-4}$ and $2.33 \times 10^{-4} \%$, by thorium: $7.5 \times 10^{-4}$ and $6.84 \times 10^{-4} \%$. 
The coefficients of radioactive equilibrium between radium and uranium for these areas are shifted towards uranium and are equal to 0.59 and 0.64 . The thorium-uranium ratio is close to three units (3.19 and 2.93). The minimum values of uranium and thorium are noted for sandstones of the Larkinskaya area: uranium - $1,43 \times 10^{-4}$; thorium $-4.3 \times 10^{-4} \%$. The radioactive equilibrium is shifted towards uranium $(k=0.47)$, and the thorium-uranium ratio here is about 3.0 units.

Intermediate values of the mass fractions of $U$ and Th turned out to be for siltstones and sandstones of the Kechimovskaya and Ugutskaya areas: uranium - $1.94 \times 10^{-4}$ and $1.98 \times 10^{-}$ $4 \%$; thorium $-5.81 \times 10^{-4}$ and $5.47 \times 10^{-4} \%$. The radioactive equilibrium here is shifted towards uranium and is 0.64 and 0.55 . Thorium-uranium ratios -3.0 and 2.76 . Thus, the research results indicate an increase in the mass fractions of naturally radioactive elements in the series sandstones - sandstone-siltstone open pits - siltstones. The stable behavior of the thorium-uranium ratio should be explained by the monomineral nature of the accessory fraction, which contains uranium and thorium in a stable ratio. The increase in the level of natural radioactivity in the direction from sandstones to siltstones should be explained by the difference in fragility (ability to disintegrate) between quartz and grains of active accessories. The reason for the shift in the radioactive equilibrium between uranium and radium is not completely clear yet. It can be said only about a stable ratio between radium and uranium in the series of sandstones - siltstone in relation to the considered areas of the Tyumen region.

\section{References}

1. E. I. Leontiev, L. M. Dorognitskaya, G. S. Kuznetsov, A. Ya. Malykhin, Study of oil and gas reservoirs in Western Siberia by geophysical methods, 240 (1974)

2. V. M. Gavshin, Geology and radio-geology of Central Siberia, 173 (1985)

3. I. I. Pluman, Geochemistry, 5, 756 (1975).

4. D. A. Kozhevnikov, Neutron characteristics of rocks and their use in oil and gas field geology, 221 (1982)

5. R. P. Gottich, Radioactive elements in oil and gas geology, 253 (1980)

6. V. V. Khabrov, O. M. Nelepchenko, E. N. Volkov, O. V. Bartashevich, Soviet Geology, 10, 94 (1980)

7. Yu. B. Davydov, On the possibility of separate determination of uranium and thorium according to gamma and beta measurements in dry wells, 50, 40 (1967)

8. T. A. Glushkova, E. A. Savin, A. G. Talalay, University Bulletin. Mountain Journal, 4, 97 (2018)

9. T. A. Glushkova, A. G. Talalay, I. E. Shinkaryuk, IOP Conference Series: Earth and Environmental Science, 272 (2)

10. S. A. Igumnov, Issues of exploratory geophysics, 50, 45 (1967) 